\title{
GAMBARAN HISTOPATOLOGI EKSPRESI INTERFERON GAMMA (IFN $\gamma$ ) PADA FIBROADENOMA MAMMAE (FAM) DAN INVASIVE NO SPECIAL TYPE (NST) BREAST CARCINOMA
}

\author{
INTERFERON GAMMA EXPRESSION PROFILE (IFNy) ON FIBROADENOMA \\ MAMMAE (FAM) AND INVASIVE BREAST CARCINOMA OF NO SPECIAL TYPE
}

(NST)

\author{
Yuni Prastyo K, Siti Amarwati, Udadi Sadhana, Dik Puspasari \\ Bagian Patologi Anatomi Fakultas Kedokteran Universitas Diponegoro/ RSUP Kariadi Semarang \\ Korespondensi: dr. Yuni Prastyo K, Sp. PA. Email : unique_pathologist@yahoo.co.id
}

\begin{abstract}
ABSTRAK
International Agency for Research Cancer tahun 2012 melaporkan bahwa 1,7 juta wanita menderita kanker payudara. Penyakit ini masih menjadi penyebab utama kematian kanker pada wanita. Fibroadenoma merupakan lesi jinak payudara yang sering ditemukan. Terdapat 50\% dari seluruh biopsi payudara.. Morfologi terbanyak pada keganasan payudara adalah Invasive NST breast carcinoma sebanyak 70\%-80\%. Berbagai faktor terlibat dalam pertumbuhan tumor payudara, antara lain genetika, diet, faktor reproduksi, hormon dan imunitas. Gangguan mekanisme imun memiliki peran penting pada patogenesis terjadinya tumor. Wanita dengan tumor payudara memperlihatkan adanya kekacauan pada sistem imun tubuh. Hal ini ditandai dengan rendahnya kadar Interferon $\gamma$ dan peningkatan IL4, IL6 serta IL10. Murine melaporkan tentang peran penting Interferon ${ }_{\gamma}$ dalam kekebalan tumor. Ketika terjadi penurunan kadarnya, secara spontan akan memicu tumbuhnya tumor. Interferon $\gamma$ sitotoksik pada beberapa sel-sel ganas dan memiliki aktivitas anti-angiogenik. Namun, penggunaannya di klinis masih terbatas. Tujuan penelitian adalah untuk membuktikan adanya perbedaan ekspresi Interferon ${ }_{\gamma}$ pada sediaan histopatologi. yang terdiagnosis sebagai fibroadenoma mammae intrakanalikular dan perikanalikular variant (FAM) dan Invasive No Special Type (NST) breast carcinoma. Penelitian ini merupakan jenis penelitian analitik observasional dengan desain case control. Sampel terbagi 2 yaitu kelompok dengan diagnosa fibroadenoma mammae intrakanalikular dan perikanalikular variant sebanyak 10 sampel dan kelompok Invasive NST breast carcinoma sebanyak 27 sampel. kemudian dilanjutkan pemeriksaan imunohistokimia interferon $\gamma$. Data yang terkumpul tidak terdistribusi normal, sehingga dilakukan uji non-parametrik dengan menggunakan uji Fishers exact dan hipotesis satu arah (one-sided). Data hasil Penelitian diolah menggunakan uji Fisher's exact dan hipotesis satu arah (one sided) dan didapatkan tingkat signifikansi $\mathrm{p}=0.036(\mathrm{p}<0.05)$. Terdapat perbedaan proporsi ekspresi Interferon $\gamma$ yang positif antara FAM intrakanalikular dan perikanalikular variant dan NST, di mana proporsi ekspresi positif Interferon $\gamma$ pada FAM intrakanalikular dan perikanalikular variant lebih besar dari pada NST. Secara statistik perbedaan ini bermakna $(\mathrm{p}<0.05)$. Dapat disimpulan bahwa terdapat perbedaan bermakna tentang ekspresi interferon ${ }_{\gamma}$ pada sediaan histopatologi fibroadenoma mammae intrakanalikular dan perikanalikular variant dibanding pada sediaan Invasive NST breast carcinoma
\end{abstract}

Kata Kunci: Interferon $\gamma$, fibroadenoma mammae, Invasive breast carcinoma of No Special Type

\begin{abstract}
International Agency for Cancer Research in 2012 reported that 1.7 million women suffer from breast cancer. The disease is still the leading cause of death of cancer in women. Fibroadenoma mammae is a benign lesion that are often found. There are 50\% of all mamae biopsies. The most common type in breast cancer is invasive breast carcinoma of no special type (70\%-80\%). Various factors are involved in the growth of breast tumors, like genetics, diet, reproductive factors, hormones and immunity. Impaired immune mechanisms have an important role in the pathogenesis of tumors. Women with breast tumors showed havoc on the body's immune system. It is characterized by low levels of interferon ${ }_{\gamma}$ and an increase in IL4, IL6 and IL-10. Murine report that Interferon ${ }_{\gamma}$ an important role in tumor immunity. When there is a drop in levels, will spontaneously trigger the growth of tumors. Interferon ${ }_{\gamma}$ cytotoxic in several malignant cells and have anti-angiogenic activity. However, in clinical use is still limited. Aim of research : to prove the existence of differences the expression of interferon
\end{abstract}




\begin{abstract}
$\gamma$ on histopathology preparation. diagnosed as fibroadenoma mammae intrakanalikular dan perikanalikular variant and Invasive breast carcinoma of no special type. This study is observational analytic with case control design. Samples were divided into 2 groups with the diagnosis of fibroadenoma mammae intrakanalikular dan perikanalikular variant (FAM) as many as 10 samples and Invasive breast carcinoma of No Special Type (NST) as many as 27 samples. then continued interferon ${ }_{\gamma}$ immunohistochemical examination. The collected data were not normally distributed, so that a non-parametric tests using Fishers exact test and a hypothesis one direction (one-sided). Research result: Using Fisher's exact test and a hypothesis one direction (one sided) obtained a significance level of $p=0.036(p<0.05)$. There are differences in the proportion of positive expression of interferon $\gamma$ between FAM intrakanalikular and perikanalikular variant, and NST, where the proportion of positive expression of interferon $\gamma$ in FAM intrakanalikular and perikanalikular variant is greater than the NST. This difference was statistically significant $(p<0.05)$. There is a significant difference on the expression of interferon $\gamma$ on histopathologi preparation betwen fibroadenoma mammae intrakanalikular and perikanalikular variant, and Invasive breast carcinoma of No Special Type
\end{abstract}

Keywords: Interferon $\gamma$, fibroadenoma mammae, Invasive breast carcinoma of No Special Type

\section{PENDAHULUAN}

International Agency for Research Cancer (IARC) tahun 2012 melaporkan bahwa 1,7 juta wanita menderita kanker payudara, bahkan 5 tahun kedepan diperkirakan 6,3 juta manusia akan mengalami kelainan yang sama (WHO,2013; IARC,2012). Penyakit ini pada tahun 2012 masih menjadi penyebab utama kematian kanker pada wanita dengan jumlah kematian 522.000 per tahun (Larsen et al, 2013). Tumor payudara terbagi menjadi dua yaitu lesi jinak dan ganas. Fibroadenoma mammae merupakan lesi jinak payudara yang paling sering ditemukan (Robbins dan Kumar, 2014; Rosai dan Ackerman, 2004). Breast Cancer Institute melaporkan bahwa insidensi fibroadenoma mammae sekitar 9\% dari populasi wanita (NSW, 2005). Literatur lain menyebutkan FAM ditemukan sekitar 50\% dari seluruh biopsi payudara (Greenberg et al; 1998). Invasive breast cancer merupakan karsinoma terbanyak pada wanita. Gambaran morfologi invasive terbesar adalah Invasive breast carcinoma of no special type sebanyak 70\%-80\% (Robbins dan Kumar 2014). WHO menyebutkan bahwa kasus NST tersebut terdapat 40\%-75\% dari kasuskasus yang dipublikasikan (WHO,2013).

Setelah dilakukan operasi pengambilan tumor FAM, klinisi tetap melakukan pemantauan dan evaluasi secara berkala (Greenberg et al; 1998). Studi dengan skala luas mempresentasikan bahwa fibroadenoma mammae memiliki resiko dalam jangka panjang berubah menjadi breast carcinoma (a low long-term risk) (Rosai dan Ackerman; 2004). Transformasi keganasan pada komponen epithelial FAM dilaporkan sebanyak 0,002\%-0,0125\% (Rosai dan Ackerman, 2004;
Greenberg et al, 1998). Penelitian lain yang dilakukan memperlihatkan adanya peningkatan resiko keganasan payudara sebanyak 1,3-2,1x pada wanita dengan FAM dan menyebutkan bahwa setelah dilakukan pengambilan tumor, terdapat pembesaran kembali sekitar $25 \%$ selama follow up (Greenberg et al; 1998).

Tumor payudara, seperti juga tumor lainnya, tumbuh melewati berbagai tahapan mulai dari jinak, bertransformasi menjadi ganas dan invasive kemudian bermetastasis. Predisposisi genetik ditambah dengan lingkungan tertentu mengubah sel lebih rentan terhadap paparan karsinogenik. Proses ini membutuhkan waktu yang sangat lama. Berbagai faktor terlibat dalam pertumbuhan tumor payudara, antara lain genetika, diet, faktor reproduksi, hormon dan imunitas (Robbins dan Kumar, 2014; Rosai dan Ackerman, 2004; WHO, 2012; Suresh et al, 2011).

Postulat Virchow menyebutkan bahwa cancer bermula pada lokasi terjadinya inflamasi kronik. Proses inflamasi menyebabkan juga proses proliferasi sel. Jaringan yang terkena jejas, akan menghasilkan proses nekrotik atau kematian sel. Sel-sel yang telah nekrotik ini akan merilis sinyal-sinyal pro-inflamasi ke lingkungan mikro jaringan disekitarnya. Sinyal-sinyal ini akan mensekresikan bioaktif untuk menstimulasi selsel disekitarnya untuk berproliferasi (De Nardo dan Coussens, 2007) Proses proliferasi dan inflamasi akan berhenti ketika agen penyebab berhasil dihilangkan dan proses regenerasi jaringan telah selesai. Namun sebaliknya, ketika sebab jejas masih ada, produk sel-sel yang mati terus berguliran, maka siklus proliferasi sel juga terus akan berjalan. Sinyal mitogenik yang terus 
menerus ini akan memfasilitasi tumbuhnya tumor yang 'insipiens' (Hanahan dan Weinberg, 2011). Sebagai tambahan, sel-sel inflamasi juga me-release oksigen radikal spesifik (ROS) yang merupakan mutagen aktif sehingga terjadi instability gen yang mempercepat berkembangnya tumor (Hanahan dan Weinberg, 2011; NSW, 2005). Saat homeostasis jaringan berubah, makrofag dan sel mast akan mengeluarkan sitokin, kemokin dan mediator bioaktif lainnya untuk merekrut leukosit dari sirkulasi ke dalam jaringan yang rusak. Rekruiting ini akan mengeliminasi agen patogen in situ. Namun pada saat yang bersamaan, sel dendritik akan mengambil antigen asing (termasuk antigen tumor) dan bermigrasi ke organ limfoid. Dalam organ tersebut, sel dendritik akan mempresentasikan antigen ke sel- sel imun adaptif. Pada inflamasi kronik, yang terjadi kemudian adalah limfosit Treg, sel limfosit Thelper2 dan sel B yang teraktifasi akan terakumulasi. Sel-sel ini akan mensekresikan pro-growth faktor sitokin IL4, IL6, IL10, dan TGF $\beta$ yang memperbesar respon sel-sel imun pro-tumor dan menghentikan aktifitas sel T sitotoksik (Hanahan dan Weinberg, 2011). Bagaimana mekanisme inflamasi kronik mempromosikan tumor dapat dilihat pada gambar I.1. Sel tumor yang telah terbentuk juga memiliki kemampuan untuk mempertahankan sinyal proliferatif. Sel tumor dapat menghasilkan faktor pertumbuhan sendiri dan merangsang sel normal disekitarnya untuk mensuplai faktor-faktor pertumbuhan (Hanahan dan Weinberg, 2011).

Gangguan mekanisme imun memiliki peran penting pada patogenesis terjadinya tumor. Penurunan jumlah dan fungsi limfosit, kelainan proliferasi limfoid dilaporkan pada banyak studi tentang tumor(Luizet al, 2012). Berbagai penelitian menunjukkan bahwa sitokin memiliki aktivitas anti-tumor yang luas dan telah diaplikasikan ke berbagai terapi tumor (Sylvia dan Kim, 2011). Sebagai contoh, FDA mengesahkan dua sitokin untuk pengobatan tumor yaitu Interleukin 2 (IL2) dan Interferon $\alpha$ (IFN $\alpha$ ). Hellenic Oncology Group melaporkan berkurangnya fenomena autoimun di antara pasien melanoma selama atau setelah terapi ajuvan Interferon $\alpha$. Selain itu digunakan pula untuk pengobatan beberapa keganasan hematologi, sarkoma kaposi dan tumor ginjal. Penelitian lain melaporkan efektif juga sebagai terapi untuk hairy cell leukemia dan leukemia myelogenous kronis (Sylvia dan Kim, 2011). IL10 sendiri dilaporkan berfungsi menghambat sitokin Th1 pada penderita tumor vesica urinaria (Luo et al., 2012). Penderita dengan tumor laring dan supraglotis memperlihatkan adanya defisiensi Interferon ${ }_{\gamma}$ dan menunjukkan perbaikan setelah keadaan ini diperbaiki pasca operasi (Luiz et al., 2012).

Biomarker pro-inflamasi dan respon imun terkait dengan resiko tumor payudara dan prognosisnya (NIH, 2014). Wanita dengan tumor payudara memperlihatkan adanya kekacauan pada sistem imun tubuh. Hal ini ditandai dengan rendahnya kadar Interferon ${ }_{\gamma}$ dan peningkatan IL4, IL6 serta IL10. Regulasi imun dapat menjelaskan seberapa besar kekacauan yang terjadi dalam sistem tubuh akibat tumor dan pengaruhnya pada survival outcomes (Cecile et al., 2011). Penelitian sebelumnya melaporkan adanya korelasi antara breast cancer dengan faktor polimorfisme gen yang mengontrol sitokin Interferon ${ }_{\gamma}$ dan IL-10 (Julie et al., 2005). Murine melaporkan juga tentang peran penting Interferon ${ }_{\gamma}$ dalam kekebalan tumor. Ketika terjadi penurunan kadarnya, secara spontan akan memicu tumbuhnya tumor. Interferon ${ }_{\gamma}$ memiliki aktivitas anti-angiogenik sehingga sitotoksik pada beberapa sel-sel ganas. Namun, penggunaannya di klinis masih terbatas (Sylvia dan Kim, 2011).

Dari latar belakang diatas maka penulis berkeinginan untuk mengadakan penelitian tentang apakah ada perbedaan ekspresi Interferon $\gamma$ pada sediaan histopatologi tumor payudara baik yang di diagnosis sebagai Fibroadenoma mammae intrakanalikular dan perikanalikular variant maupun pada sediaan Invasive breast carcinoma of no special type.

\section{METODE}

Ruang lingkup disiplin ilmu penelitian ini meliputi bidang ilmu Patologi Anatomi, dan Patobiologi. Penelitian ini merupakan jenis penelitian analitik observasional, dengan desain case control. Tujuan penggunaan desain ini adalah membedakan variabel ukur interferon $\gamma$ pada dua kelompok. Pemeriksaan histopatologi dilakukan di Laboratorium Patologi Anatomi Fakultas Kedokteran Universitas Diponegoro dan RSUP Dr Kariadi Semarang serta pengecatan imunohistokimia interferon $\gamma$ dilakukan di Laboratorium Patologi Anatomi Fakultas Kedokteran Universitas Gajah Mada. Kemudian, ekspresi interferon $\gamma$ dibaca oleh 2 orang ahli 
patologi anatomi di Laboratorium Patologi Anatomi Fakultas Kedokteran Universitas Diponegoro Semarang.

Penelitian dilakukan Juli sampai Desember 2015. Populasi adalah slide HE (Hematoxillin Eosin) dan blok parafin yang telah di diagnosa Fibroadenoma mammae, dan Invasive breast carcinoma of No special Type di Laboratorium Patologi Anatomi RSUP dr. Kariadi Semarang pada 2 Januari 2012 sampai 31 Desember 2014. Sampel penelitian adalah slide HE dan blok parafin yang memenuhi kriteria inklusi dan eksklusi. Kemudian memperhatikan hal-hal berikut ini: gambaran morfologi histopatologi yang memperlihatkan minimal 500 sel tumor, sedikit area nekrosis, serta bukan dari sediaan Frozen Section (FS). Sampel terbagi menjadi 2 kelompok yaitu : Kelompok dengan diagnosis Fibroadenoma mammae, intrakanalikular dan perikanalikular variant sebanyak 10 sampel, serta kelompok Invasive carcinoma of No Special Type sebanyak 27 sampel. Variabel bebas yang diteliti adalah ekspresi Interferon $\gamma$ pada blok histopatologi. sedangkan variabel tergantung adalah jenis tumor payudara dengan lesi jinak diwakili oleh sampel dengan diagnosis Fibroadenoma mammae intrakanalikular dan perikanalikular variant (skala ordinal) sedangkan lesi ganas yang diwakili oleh sampel dengan diagnosis Invasive breast carcinoma of No Special Type. Ekpresi Interferon $\gamma$ adalah data primer hasil penghitungan skor selsel tumor yang tercat positif terhadap antibodi
Interferon $\gamma$ pada sampel, dengan hasil positif apabila sitoplasma sel tercat coklat (Tunon et al, 2007) dan dilakukan skoring semi kuantitatif. Data hasil pengecatan Interferon $\gamma$ kemudian dibaca oleh dua orang ahli patologi menggunakan metode semi kuantitatif dengan penetapan skor seperti pada tabel 4.1. Penilaian setiap slide dilakukan sebanyak 10x / lapang pandang besar (400X) secara acak/random. Kemudian dilakukan rerata hasil per-kelompok. Hasil positif adalah jika rerata ekspresi pengecatan interferon $\gamma$ lebih dari nol dari 10 lapang pandang besar (LPB). Sedangkan hasil negatif jika rerata ekspresi pengecatan Interferon $\gamma$ sama dengan nol dari 10 lapang pandang besar. Skala yang digunakan pada variabel ini adalah skala ordinal.

Data yang terkumpul akan melalui proses editing, coding, entrying, dan cleaning data, kemudian dilakukan analisa statistik deskriptif dan analitik. Data yang terkumpul tidak terdistribusi normal, sehingga dilakukan uji nonparametrik dengan menggunakan uji Fishers exact dan hipotesis satu arah (one-sided). Analisis histopatologi dimulai dengan blok parafin yang dipotong tipis, dilanjutkan dengan pengecatan imunohistokimia Interferon $\gamma$. Hasilnya diperiksa oleh dua orang ahli patologi anatomi. Penelitian ini telah mendapat ethical clearance dari komisi Etik Penelitian Kesehatan dan Kedokteran Universitas Diponegoro dan RSUP dr. Kariadi dengan nomor 279/EC/FK-RSDK/2015 dan surat ijin penelitian dengan nomor DL.00.02/1.11/1810/2015.

\section{HASIL DAN PEMBAHASAN}

Tabel 5.1. Distribusi frekuensi jenis tumor payudara

\begin{tabular}{lcc}
\hline Jenis tumor payudara & Frekuensi (n) & Persentase (\%) \\
\hline FAM & 10 & 27 \\
NST (grade I, II, III) & 27 & 73 \\
\hline Total & 37 & 100 \\
\hline
\end{tabular}



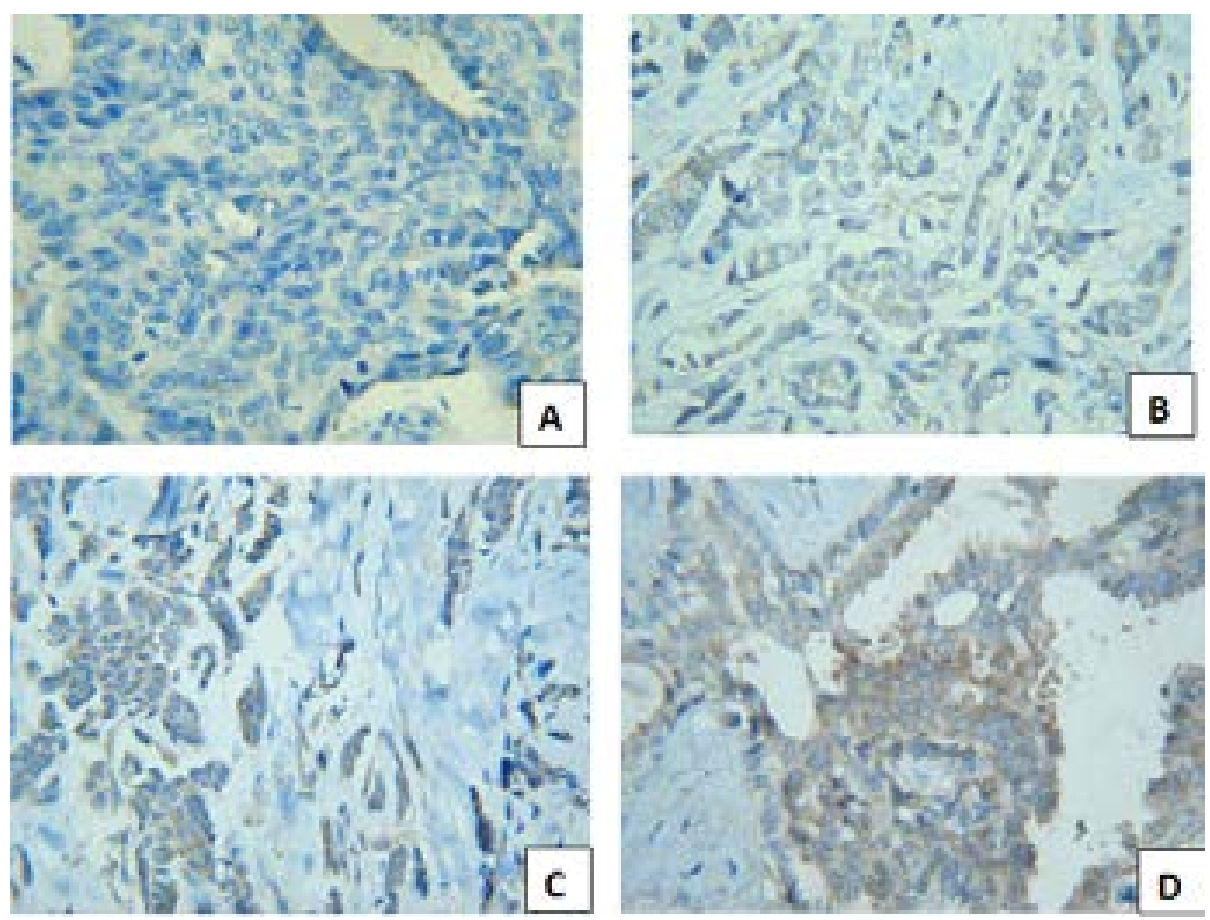

Gambar 1. Skoring ekspresi Interferon $\gamma$. A. Skor 0. B. Skor 1. C. Skor 2. D. Skor 3. Perbesaran mikroskop cahaya $400 x$ dengan pewarnaan imunohistokimia (Sumber Foto: Data Primer, 2015).

Tabel 5.2. Distribusi frekuensi ekspresi interferon $\gamma$

\begin{tabular}{ccc}
\hline Ekspresi interferon $\boldsymbol{\gamma}$ & Frekuensi (n) & Persentase (\%) \\
\hline Negatif** & 14 & 37.8 \\
Positif* & 23 & 62.2 \\
Total & 37 & 100 \\
\hline
\end{tabular}

Keterangan :

*Positif: rerata ekspresi pengecatan interferon $\gamma$ lebih besar dari nol dari 10 lapang pandang besar

**Negatif: rerata ekspresi pengecatan interferon $\gamma$ sama dengan nol dari 10 lapang pandang besar

Tabel 5.3 Crosstab perbandingan proporsi ekspresi interferon $\gamma$ antara FAM dan NST

\begin{tabular}{|c|c|c|c|c|c|c|}
\hline \multicolumn{7}{|c|}{ Ekspresi interferon $\gamma$} \\
\hline \multirow{2}{*}{$\begin{array}{c}\text { Jenis } \\
\text { tumor } \\
\text { payudara }\end{array}$} & \multicolumn{2}{|c|}{ Positif* } & \multicolumn{2}{|c|}{ Negatif** } & \multicolumn{2}{|c|}{ Total } \\
\hline & $\begin{array}{l}\text { Frekuensi } \\
\text { (n) }\end{array}$ & Persentase (\%) & $\begin{array}{l}\text { Frekuensi } \\
\text { (n) }\end{array}$ & $\begin{array}{c}\text { Persentase } \\
(\%)\end{array}$ & $\begin{array}{l}\text { Frekuensi } \\
\text { (n) }\end{array}$ & $\begin{array}{c}\text { Persentase } \\
(\%)\end{array}$ \\
\hline FAM & 9 & 90 & 1 & 10 & 10 & 100 \\
\hline NST & 14 & 51.8 & 13 & 48.2 & 27 & 100 \\
\hline
\end{tabular}

Keterangan :

*Positif: rerata ekspresi pengecatan interferon $\gamma$ dari 10 lapang pandang besar lebih dari nol

**Negatif: rerata ekspresi pengecatan interferon $\gamma$ sama dengan nol dari 10 lapang pandang besar 


\section{Perbandingan ekspresi interferon $\gamma$ \\ antara FAM dan NST}

=IFN gamma positif = IFN gamma negatif

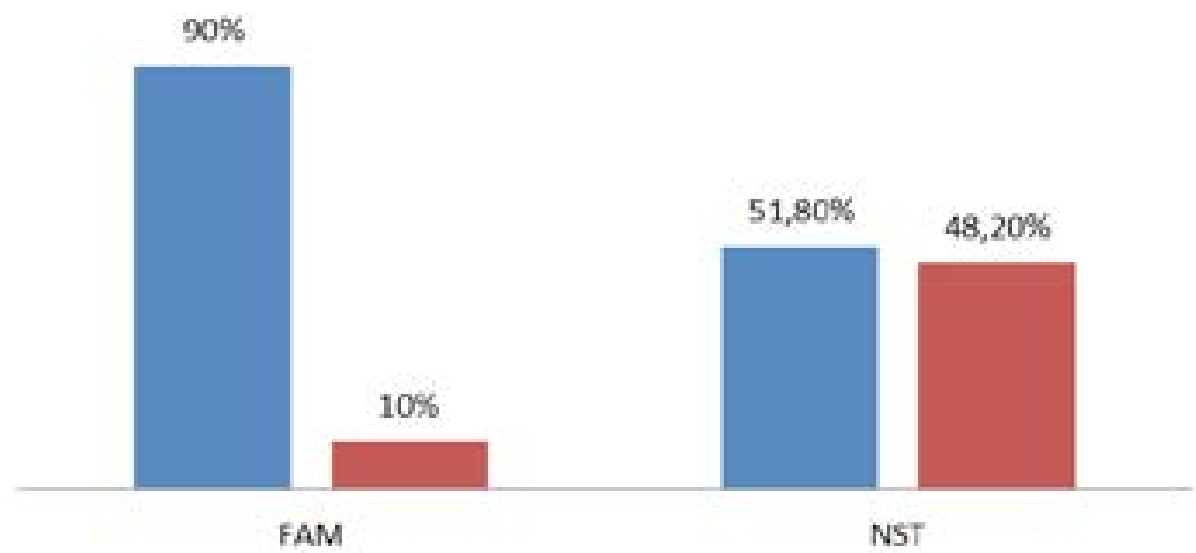

Diagram 5.1. Perbandingan ekspresi interferon $\gamma$ antara FAM dan NST

Tabel 5.4. Uji Hipotesis

\begin{tabular}{ccccc}
\hline Value & Df & $\begin{array}{c}\text { Asymp. Sig. } \\
\text { (2-sided) }\end{array}$ & $\begin{array}{c}\text { Exact Sig. } \\
\text { (2-sided) }\end{array}$ & $\begin{array}{c}\text { Exact Sig. } \\
\text { (1-sided) }\end{array}$ \\
\hline $\begin{array}{c}\text { Pearson Chi-Square } \\
4.515^{\text {a }}\end{array}$ & 1 & .034 & & \\
$\begin{array}{c}\text { Continuity Correction } \\
\text { b.039 }\end{array}$ & 1 & .081 & & \\
Likelihood Ratio & & & & \\
5.187 & 1 & .023 & .056 & .036 \\
$\begin{array}{c}\text { Fisher's Exact Test } \\
\text { N of Valid Cases } \\
37\end{array}$ & & & & \\
\hline
\end{tabular}

Tabel 5.4. adalah tabel uji hipotesis untuk menguji tingkat signifikansi perbedaan proporsi ekspresi Interferon $\gamma$ antara FAM intrakanalikular dan perikanalikular variant dengan NST, menggunakan uji Chi Square didapatkan 1 sel yang nilai expected count-nya kurang dari 5, maka tidak memenuhi syarat menggunakan uji Chi Square. Sebagai alternatif menggunakan uji Fisher's exact dan hipotesis satu arah (one sided) didapatkan tingkat signifikansi $\mathrm{p}=0.036$ $(\mathrm{p}<0.05)$. Terdapat perbedaan proporsi ekspresi Interferon $\gamma$ yang positif antara FAM dan NST, di mana proporsi ekspresi positif Interferon $\gamma$ pada FAM intracanalicular dan pericanalicular variant lebih besar dari pada NST. Secara statistik perbedaan ini bermakna $(\mathrm{p}<0.05)$.

Sistem kekebalan tubuh memiliki tiga peran utama dalam pencegahan tumor. Pertama, sistem kekebalan tubuh dapat melindungi host dari virus yang menstimulasi tumbuhnya tumor dengan menghilangkan atau menekan infeksi virus tersebut. Kedua, waktu yang lebih cepat untuk menghapus patogen dan resolusi dari proses inflamasi, dapat mencegah pembentukan inflammatory environment tumor genesis. Ketiga, sistem kekebalan tubuh dapat mengidentifikasi dan menghilangkan sel-sel tumor berdasarkan ekspresi antigen tumor. Proses ketiga ini disebut tumor immune surveillance, di mana sistem kekebalan tubuh mengidentifikasi sel-sel kanker dan atau prakanker dan kemudian berusaha menghilangkannya sebelum menyebabkan kerusakan (Swan dan Smith, 2007; Pardoll, 2003).

Implikasi dari pengawasan sistem imun dan mekanisme kekebalan untuk pertahanan tumor. Jika sistem imun berhasil mendeteksi tumor berdasarkan neo antigen mereka dalam perubahan genetik, tumor akan hilang sebelum jelas secara 
klinis. Mekanisme resistensi dari pengamatan sistem imun harus diaktifkan agar tumor dapat bertahan hidup. Sistem imun dapat mendeteksi keberadaan sel tumor (Pardoll, 2003) (Gambar 6.2)

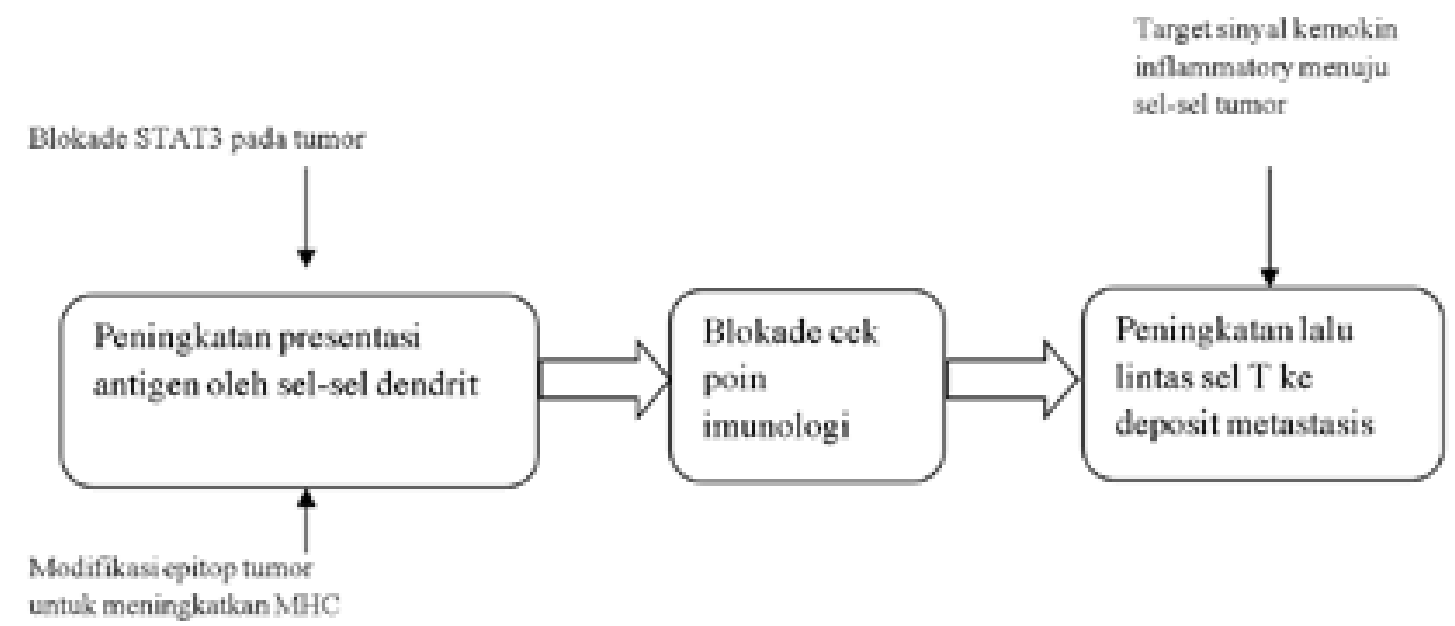

Gambar 6.2. Mekanisme sistem imun mendeteksi keberadaan sel tumor.

Inisiasi respon imun melibatkan strategi yang meningkatkan targeting dan presentasi antigen oleh sel-sel dendritik. Batasan peran dari STAT3 (Signal Transducer and Activator of Transcriptor) dalam memblok surveillance imun menunjukkan bahwa blokade STAT3 meningkatkan peran sel dendritik dalam mempresentasikan antigen tumor. Sekali teraktivasi, respons anti-tumor secara signifikan ditingkatkan melalui blokade check point imunologik. Akhirnya, terjadi peningkatan lalu lintas aktivasi sel-sel $\mathrm{T}$ ke dalam deposit metastasis. Hal ini berperan penting dalam membangkitkan respon anti-tumor secara maksimal (Pardoll, 2003).

Tabel 6.1. Perbedaan antara sel normal dan sel kanker

\begin{tabular}{|c|c|c|}
\hline Sel normal & Sel kanker & Implikasi pada imunitas terhadap kanker \\
\hline Genom stabil & Perubahan genetik multipel & Munculnya neoantigen multipel \\
\hline Transkriptom stabil & Instabilitas epigenetik mayor & Perubahan kadar densitas antigen \\
\hline $\begin{array}{l}\text { Tidak ada invasi } \\
\text { jaringan }\end{array}$ & $\begin{array}{l}\text { Invasi dan metastasis merupakan } \\
\text { gambaran utama }\end{array}$ & $\begin{array}{l}\text { Berpotensi menginduksi aktivasi inflamasi imunitas } \\
\text { alamiah dan adaptif }\end{array}$ \\
\hline $\begin{array}{l}\text { Pola ekspresi } \\
\text { sitokin dan faktor } \\
\text { pertumbuhan yang } \\
\text { stabil }\end{array}$ & $\begin{array}{l}\text { Ekspresi faktor pertumbuhan seperti } \\
\text { sitokin dan VEGF dan TGF- } \beta \text { yang } \\
\text { abnormal }\end{array}$ & $\begin{array}{l}\text { Berpotensi mempunyai efek inhibitori lokal pada } \\
\text { imunitas alamiah dan adaptif }\end{array}$ \\
\hline
\end{tabular}

Tabel 6.1 memperlihatkan, terdapat perbedaan yang spesifik antara sel yang normal dengan sel tumor baik dari komposisi antigen maupun perilaku biologis yang menyebabkan reaksi pada sistem imun. Karakteristik tersebut terkait langsung dengan kerusakan dalam jaringan yang merupakan elaborasi dari pro-inflammatory signal. Signal ini berasal dari berbagai sitokin dan kemokin yang menjadi inisiator sentral respon imun alamiah dan adaptif (Pardoll, 2003).

Neoplasia terjadi sebagai akibat dari perubahan seluleryang mengganggu keseimbangan antara pertumbuhan sel dankematian sel. Perubahan ini bisa disebabkan oleh ekspresi yang berubah dari beberapa faktor termasuk Interferon $\gamma$. Sitokin ini merupakan peptide dengan BM (berat molekul) $17 \mathrm{kDa}$ yang disekresikan oleh limfosit dan Sel NK sebagai respon terhadap tantangan antigen, yang memiliki aktivitas antivirus, menghambat pertumbuhan sel, dan memodulasi diferensiasi sel. Interferon $\gamma$ bekerja melalui aktivasi reseptor pada membran sel..$^{24,25}$ Kemampuan Interferon $\gamma$ untuk menghambat pertumbuhan beberapa sel tumor, termasuk sel-sel tumor payudara, telah dibuktikan dalam berbagai studi. Pada beberapa literatur dikatakan bahwa Interferon $\gamma$ mengobati berbagai 
macam tumor dengan memperantarai efek anti proliferasi epitel tumor dan sel tumor payudara (Tunon et al, 2007; Stang et al, 2007; Hong et al, 2013). Penulis lain berpendapat bahwa pada selsel epitel payudara, efek anti proliferasi Interferon $\gamma$ terjadi melalui upregulasi anggota keluarga molekul apoptosis lewat penekanan ekspresi bcl-2 (Tunon et al, 2007). Penelitian Ghavami et al (2009) menyebutkan bahwa Interferon $\gamma$ juga menginduksi apoptosis melalui reseptor pada IRF1 (reseptor interferon 1) sel tumor payudara yang dimediasi oleh caspase (Ghavami et al, 2009; Gao et al, 2009).

Jalur aktivasi Interferon $\gamma$ memainkan peran kunci dalam anti-proliferasi pada 13C (Indole3-carbinol). Pada tingkat sel, menyebabkan hambatan pertumbuhan sel pada fase G1 dari siklus sel. Jalur aktivasi interferon $\gamma$ dalam anti- proliferasi (Chatterji et al, 2004). 13C (indole3-carbinol) berpotensi memediasi efek melalui protein sel target dan merangsang ekspresi IFN $\gamma$-R1. Peningkatan IFN $\gamma-\mathrm{R} 1$ membuat sel-sel lebih responsif terhadap efek yang diakibatkan dari sinyal Interferon $\gamma$, yaitu menghambat pertumbuhan sel dan meningkatkan induksi dari STAT1 (Signal Transducer and Activator of Transcriptor). Jalur 13C dan Interferon $\gamma$ akhirnya berkumpul untuk mengistirahatkan secara efektif siklus sel G1 dan meningkatkan regulasi inhibisi CDK (Cyclin Dependent Kinase) pada sel tumor payudara (Chatterji et al, 2004). Penelitian yang ditunjukkan oleh Tunon et al (2007) memperlihatkan bahwa ada perbedaan prosentase sampel positif Interferon $\gamma$ pada beberapa kelompok tumor payudara seperti yang ditunjukkan pada tabel 6.2.

Tabel 6.2. Perbedaan intensitas pengecatan dan sampel yang positif pada beberapa kelompok tumor payudara.

\begin{tabular}{|c|c|c|c|c|c|c|c|}
\hline & \multicolumn{2}{|c|}{ Interferon $\gamma$} & \multicolumn{2}{|c|}{ Interferon $\gamma$-R $\alpha$} & \multicolumn{3}{|c|}{ Interferon $\gamma$-R $\beta$} \\
\hline & \multirow{2}{*}{$\begin{array}{l}\text { \% positif } \\
\text { sample }\end{array}$} & \multirow{2}{*}{$\begin{array}{l}\text { Optical } \\
\text { density }\end{array}$} & \multirow{2}{*}{$\begin{array}{l}\text { \% positif } \\
\text { samples }\end{array}$} & \multirow{2}{*}{$\begin{array}{l}\text { Optical } \\
\text { density }\end{array}$} & \multicolumn{2}{|c|}{$\%$ positif samples } & \multirow{2}{*}{$\begin{array}{l}\text { Optical } \\
\text { density }\end{array}$} \\
\hline & & & & & Cytoplasm & nucleus & \\
\hline \multirow[t]{2}{*}{ Benign lesions } & $70,6 \%$ & $11,4 \pm 2,5^{\mathrm{a}}$ & $88,2 \%$ & $14,9 \% \pm 2,3^{\mathrm{a}}$ & \multicolumn{2}{|c|}{$41,17 \%$} & $19,4 \pm 2,8^{\mathrm{a}}$ \\
\hline & & & & & $42,8 \%$ & $57,14 \%$ & \\
\hline \multirow[t]{2}{*}{$\begin{array}{c}\text { In situ } \\
\text { carcinoma }\end{array}$} & $35 \%$ & $30,7 \pm 8,1^{\mathrm{b}}$ & $41,4 \%$ & $18,2 \pm 2,7^{\mathrm{a}}$ & \multicolumn{2}{|c|}{$55,1 \%$} & $17,6 \pm 4,1^{\mathrm{a}}$ \\
\hline & & & & & $6,25 \%$ & $93,75 \%$ & \\
\hline \multirow[t]{2}{*}{$\begin{array}{l}\text { Infiltrating } \\
\text { carcinoma }\end{array}$} & $40 \%$ & $18,9 \pm 2,1^{\mathrm{a}}$ & $28,9 \%$ & $9,9 \pm 2,1^{\mathrm{b}}$ & \multicolumn{2}{|c|}{$22,2 \%$} & $18,6 \pm 2,9^{\mathrm{a}}$ \\
\hline & & & & & $20 \%$ & $80 \%$ & \\
\hline
\end{tabular}

Persentase tertinggi sampel positif $(70.6 \%)$ pada Interferon $\gamma$ ditemukan pada kelompok lesi jinak, sedangkan pada kasus infiltrating tumor jumlah sampel positif lebih rendah. Immunoreactions paling intens ditemukan pada tumor in situ. Persentase positif pada infiltrating tumor sama seperti yang ditemukan dalam kasus in situ dengan intesitas immunoreactions sedikit menurun (Tunon et al, 2007).

Hasil di atas sesuai dengan temuan pada penelitian ini, bahwa ekspresi interferon $\gamma$ pada lesi jinak yang pada penelitian ini diwakili oleh sampel dengan diagnosis FAM intracanalicular dan pericanalicular variant positif sebesar $90 \%$ dan negatif sebesar $10 \%$. Sedangkan untuk infiltrating tumor yang pada penelitian ini menggunakan sampel dengan diagnosa No special Type (NST) Invasive breast carcinoma dengan hasil positif, menurun sebesar $51,80 \%$, sementara di sisi lain hasil negatif meningkat sebesar 48,20\%. Dengan menggunakan uji Fisher's exact dan hipotesis satu arah (one sided) didapatkan kesimpulan bahwa perbedaan ini bermakna secara statistik dengan nilai $\mathrm{p}=0.036(\mathrm{p}<0.05)$.

\section{SIMPULAN}

Terdapat perbedaan yang bermakna tentang ekspresi interferon $\gamma$ pada sediaan histopatologi Fibroadenoma mammae intracanalicular dan pericanalicular variant (FAM) dibanding pada sediaan Invasive no special Type (NST) breast carcinoma. Ekspresi positif interferon $\gamma$ pada sediaan fibroadenoma mammae intracanalicular dan pericanalicular variant,. lebih besar dibandingkan pada jenis sediaan Invasive no special Type (NST) breast carcinoma. 
Kadar ekspresi interferon $\gamma$ fibroadenoma mammae intracanalicular dan pericanalicular variant.positif sebesar $90 \%$ dan negatif sebanyak $10 \%$. Sedangkan kadar interferon $\gamma$ untuk sediaan Invasive no special Type (NST) breast carcinoma yang positif menurun sebesar $51,80 \%$ dan yang negatif meningkat sebesar $48,20 \%$.

Terdapat penurunan ekspresi interferon $\gamma$ yang positif pada sediaan infiltrating tumor. Pada penelitian ini digunakan blok histopatologi dengan diagnosis Invasive no special Type (NST) breast carcinoma.

Interferon $\gamma$ dapat menghambat proliferasi sel-sel tumor dengan menginduksi STAT1 sehingga siklus sel pada tahap G1 berhenti. Interferon $\gamma$ juga menginduksi apoptosis sel-sel tumor dengan cara penekanan pada Bcl-2. Kedua hal tersebut merupakan mekanisme kerja interferon $\gamma$ untuk dapat menghambat proses keganasan.

\section{DAFTAR PUSTAKA}

Cecile AL, Kevin EK, 2011; Janice Post-White, Shirley F, Cathy N. Lymphocyte Recovery After Breast Cancer Treatment and Mindfulness-Based Stress Reduction (MBSR) Therapy MS3 Biological Research for Nursing. http://brn.sagepub.com.

Chatterji U, Riby JE, Taniguchi T. 2004; Indole-3-carbinol stimulates transcription of the interferon gamma receptor 1 gene and augments interferon responsiveness in human breast cancer cells. Department of Molecular and Cell Biology and the Cancer Research Laboratory. Berkeley.. 25: $1119-1128$

De Nardo, Coussens ML, 2007; Inflammation and Breast Cancer, Balancing immune response : Crostalk between adaptive immune cells during breast cancer progression. Breast Cancer Research. 15 August 2007

Gao J, Senthil M, Ren B, 2009; IRF-1 transcriptionally upregulates PUMA, which mediates the mitochondrial apoptotic pathway in IRF-1-induced apoptosis in cancer cells. Department of Surgery, Union Hospital, Huazhong University of Science and Technology, Wuhan, Hubei. China. Oct 23;17: 699-709

Ghavami S, Hashemi M, Ande SR, 2009 ; Apoptosis and Cancer: mutations and within caspase genes. Department of Physiology, University of Manitoba. Canada. July 31;46: 497-510

Greenberg R, Skornick Y, Kaplan O, 1998; Management of Breast Fibroadenomas. J Gern Inttern Med. Hanahan D, Weinberg NA, 2011; Hallmark of Cancer : The Next Generation. Elsevier.

Hong CC, Yao S, McCann SE, 2013; Pretreatment levels of circulating Th1 and Th2 cytokines, and their ratios, are associated with ER-negative and triple negative breast cancers. Department of Cancer Prevention and Control, Roswell Park Cancer Institute. New York. Jun; 139(2): 477488

IARC, 2013; Latest world cancer statistic. International Agency pro Research on Cancer, 2013; Latest World Cancer Statistic. WHO. 12 des 2013

Julie MW, Debra Bensen-Kennedy, Yuji M, Christopher J. Thoburn, Deborah A, Georgia BV, Allan DH, 2005; Biology of Blood and Marrow Transplantation; American Society for Blood and Marrow Transplantation The School of Medicine and the Sidney Kimmel Comprehensive Cancer Center, The Johns Hopkins University, Baltimore, Maryland,

Larsen MJ, Kruse TA, Tan Q, Lænkholm A-V, Bak M, 2013; Classifications within Molecular Subtypes Enables Identification of BRCA1/BRCA2 Mutation Carriers by RNA Tumor Profiling; Classifications within Molecular Subtypes Enables Identification of BRCA1/BRCA2; PLoS ONE.

Luiz CC, Maria C. Foss-Freitas, Rui CM. Mamede, Norma TF, 2012; Interferon-gamma and interleukin-10 production by mononuclear cells from patients with advanced head and neck cancer. CLINICS. Universidade de Sa ̃ Paulo (USP), Medical School of Ribeira o Preto, 
Ribeira , Brazil.

Luo Y, Eric J. Askeland, Mark RN, Michael AO, 2012; Role of IL-10 in Urinary Bladder Carcinoma and Bacillus Calmette-Guerin Immunotherapy. Department of Urology, University of Iowa, Iowa City, USA. American Journal of Immunology.

NIH Public Access, 2014; Breast Cancer Res Treat. Breast Cancer Res Treat. ; Department of Cancer Prevention and Control, Roswell Park Cancer Institute, Buffalo, USA. Author manuscript; available in PMC 2014 February 04.

NSW Breast Cancer Institute, 2005; Fibroadenoma of The Breast. http://www.bci.org.au.

Pardoll D, 2003; Does The Immune System See Tumors As Foreign or Self? Sidney Kimmel Cancer Centre, John Hopkins University School of Medicine. Maryland.; 21: 807-839

Robins, Kumar, 2014; Pathologic basic of disease, 9 edition.

Rosai, Ackermann, 2004; Surgical pathology, tenth edition, Elsevier.

Stang MT, Armstrong MJ, Watson GA . 2007; Interferon regulatory factor-1-induced apoptosis mediated by a ligand-independent fas-associated eath domain pathway in breast cancer cells. Department of Surgery, University of Pittsburgh Cancer Institute. Korea. Apr 23;26: 6420-6430

Suresh HUK, Showket H, Shirish S, Shailja P, 2011; Breast cancer and human papilloma virus infection: No evidence of HPV etiology of breast cancer in Indian women. BMC Cancer.

Sylvia L, Kim M, 2011; Cancers Cytokines in Cancer Immunotherapy. Division of Medical Oncology, Department of Medicine, University of Washington, Seattle, WA, USA. Fred Hutchinson Cancer Research Center. www.mdpi.com/journal/cancers.

Tunon IG, Ricote M, Ruiz A. 2007; Influence of IFN-gamma and its receptors in human breast cancer. Department of Cell Biology and Genetic, University of Alcala and Department of Pathology, Hospital Principe de Asturias, Alcala de Henares. Spain. Aug 14;7(158):1-11

WHO, 2012; Classification of tumours of the breast. 4th edition, lyon 